\title{
Introduction \\ The global economy and development in times of pandemic: the challenges for Latin America and the Caribbean
}

\author{
Alicia Bárcena and Mario Cimoli \\ Guest editors
}

\section{A special edition for complex times}

This special edition of CEPAL Review has been prepared in the context of the health crisis caused by the global spread of coronavirus disease (COVID-19) in 2020. The pandemic has been accompanied by the most acute economic crisis for global capitalism since the Great Depression of the 1930s. More broadly, it has brought a severe humanitarian crisis in which millions of human lives have been cut short by the virus, while the loss of production and employment has translated into worsening conditions of material well-being for vast segments of the world's population (especially in respect of health, education and nutrition) and hence severe reversals on poverty and income distribution. In this sombre global landscape, Latin America has proved to be one of the regions most affected by the pandemic. This is no accident, given the internal and external asymmetries that characterize its dysfunctional development style, a pattern described by numerous publications in the structuralist and neostructuralist literature analysing the socioeconomic and environmental dynamics of the region at different stages in its history. ${ }^{1}$

\section{Guest editors}

Alicia Bárcena is the Executive Secretary of the Economic Commission for Latin America and the Caribbean (ECLAC). Email: alicia.barcena@un.org.

Mario Cimoli is the Deputy Executive Secretary of the Economic Commission for Latin America and the Caribbean (ECLAC). Email: mario.cimoli@un.org. 
In the context of global health history, the pandemic is an ongoing phenomenon whose effects are difficult to determine and measure qualitatively and quantitatively. Prior to this health crisis, other pandemic diseases had resulted in high levels of mortality year after year in recent decades (Žižek, 2020). The question then arises as to what differentiates this pandemic from similar scourges. A plausible answer may be found in the speed of transmission and the mortality that this virus has caused in its first year of circulation. Because of this, the pandemic had an immediate effect on the labour force and thus on effective demand, production and trade. It has also shown that inequality within developing countries is a significant obstacle to the deployment of containment policies.

A variety of analysts have set out to study the impact of this global health phenomenon and offer different perspectives on the future of the economy in the aftermath of the pandemic. One example is the thinking of Chena and Pérez Caldentey (2020), who raise the question of whether the pandemic will reinforce prevailing trends in the organization and coordination of global production and finance or whether, conversely, it will be a factor for disruption and creative destruction. While this question may elicit different answers, it is clear that the health crisis will have ineluctable effects on the region's productive structure and on the prospects of advancing a process of structural and distributional change. Mitigating its negative short-term impacts with urgent measures that also take account of the long term is the way to ensure that these effects contribute to a resolution of the structural problems facing the region, particularly its technological and productive shortcomings and its high level of inequality.

\section{The contents of this edition}

With these considerations in mind, this special edition of CEPAL Review offers different perspectives on the effects of COVID-19 in the region and puts forward a variety of policy proposals aimed at dealing with the health, social and economic crisis caused by the spread of the virus, in accordance with each author's particular approach.

The material presented here can be classified by the different analytical perspectives in the 14 articles the issue contains. First, there are articles that address the subject of COVID-19 from a global standpoint. These include the pieces by Ha-Joon Chang, Giovanni Dosi, Maria Savona, and Nora Lustig and Mariano Tommasi. This special edition includes another set of articles exploring the effects of the pandemic from a regional perspective, comprising essays by Alicia Bárcena and Mario Cimoli; José Antonio Ocampo; Martín Abeles, Esteban Pérez Caldentey and Gabriel Porcile; Nicole Bidegain, Lucía Scuro and lliana Vaca Trigo; and Juan Carlos Moreno Brid and Rodrigo Morales. This group of essays is complemented by a pair of articles that analyse pandemic-related topics from a combination of global, regional and national perspectives. In this category are the essays by Benedicte Bull and Francisco Robles and by José Gabriel Palma, which also highlight the political economy challenges posed by the pandemic. The collection of articles in this edition is completed by three papers analysing the situations of individual countries, with Leonardo Lomeli writing on Mexico, Luiz Carlos Bresser-Pereira on Brazil, and Ramón López and Gino Sturla on Chile.

Of the articles with a global perspective, Chang's addresses a central and recurring theme in development debates: multilateralism. The author analyses the factors leading to the deterioration of the world trading system in the context of the neoliberal economic order that has held sway in the governance of the global economy since the 1980s. He argues that this deterioration may be opening the way to a "new" new international economic order, stemming not only from the collapse of world trade and the ongoing effects of the 2008 economic crisis, but also from changes in the global economy and in prevailing ideas, as well as other factors such as the emergence of China as a global economic power, climate change and the health crisis caused by the spread of COVID-19. 
Dosi's article analyses some trends in global capitalism prior to the pandemic and certain aspects of the latter that would seem to require a choice to be made between maintaining countries' current mode of governance (characterized by what the author calls techno-authoritarianism) or moving towards new forms of social organization. The author further argues that the health crisis has occurred in a context of increasing technologization and socioeconomic fragility. In this context, there have been very clear trends involving the worsening of functional income distribution to the detriment of wages, the widening of gaps between productivity and wages, and the explosive growth of profits (financial and non-financial).

In a similar vein, Savona examines the effects of COVID-19 in the context of the current digital transformations and employment structures in the global economy, describing some of the new policy challenges posed by the pandemic. In her analysis, she argues that the "new normal" that will emerge must recognize a "new essential" in relation to the world of work and sectors of economic activity. The set of essays with a global perspective is completed by Lustig and Tommasi's study, in which these authors analyse the link between the effects of COVID-19 and the social protection required by the most vulnerable sections of the population.

Regarding the articles with a regional perspective, this issue offers readers a variety of approaches, data and policy implications serving to provide a broader understanding of this health phenomenon in our region. The essay by Bárcena and Cimoli, setting out from the observation that Latin America and the Caribbean has been one of the regions most affected by the pandemic, analyses structural asymmetries prior to the health crisis, which revealed the dysfunctionality of the growth process in the region's countries, and argues for the need to move towards a new pattern of development.

In a similar line of analysis, Abeles, Pérez Caldentey and Porcile examine the effects of COVID-19 in the region, arguing that recovery will require large-scale fiscal policies designed to stimulate effective demand. The composition of these fiscal efforts should, according to the authors, be heavily weighted towards investment aimed at generating technological capabilities, economic diversification and increased linkages in the productive matrix.

Ocampo's essay offers a historical analysis of the impacts of COVID-19, comparing the current health crisis with the Great Depression of the 1930s, the Asian crisis of 1997 and the crisis of 2008-2009, which he calls the North Atlantic crisis. The author notes that all shocks associated with external financing, terms of trade, trade volumes and remittance levels have had less severe impacts than the current health contingency. Ocampo identifies insufficient international financial cooperation as being at the heart of these findings. From this perspective, he argues that the pandemic has hit Latin America and the Caribbean so hard mainly because of the internal structural factors that caused the economic stagnation observed in the region before the crisis, in line with the analyses in the articles by Bárcena and Cimoli and by Abeles, Pérez Caldentey and Porcile.

The set of essays written from a regional standpoint is completed with the study by Bidegain, Scuro and Vaca Trigo, who analyse the impact of the pandemic from a gender perspective, highlighting the way it has affected the economic autonomy of women in the region, and the article by Moreno Brid and Morales, who offer a subregional perspective on the effects of COVID-19 in Central America.

Turning to the articles that combine different perspectives, mention may first be made of Bull and Robles, who conduct a thorough literature review in order to explore how pandemics affect inequality in income distribution. The authors argue that the economic literature provides significant evidence that pandemics increase distributional inequality, while historiographical and political science studies suggest that they can lead to institutional crises which, in a context of mutations within elites and pressure from popular demands, can result in inequality levels being maintained. After contrasting these theoretical theses with a set of empirical data presented for the region, the authors suggest that in the COVID-19 pandemic, although there have been income transfers to the wealthier sectors 
and some changes in the composition of elites, there is little evidence that the region is witnessing an institutional crisis, given that it is these elites that have provided the political leadership during the health emergency.

In a similar line of analysis, Palma addresses the issues surrounding inequality in the region, emphasizing the case of Chile. Drawing on the theory of political economy of David Ricardo, income distribution is understood as the materialization of a conflict in which multiple stakeholders are engaged in a struggle over different interests that takes place within a particular historical, political and institutional setting as relevant as the purely economic "fundamentals". Starting from this analytical framework, Palma argues that, regardless of events over the region's history, the rich in Latin America have remained rich by virtue of the iron law of oligarchies, i.e. through a mechanism whereby dysfunctional institutions rebuild to ensure a distributive pattern that benefits the oligarchic sectors of society.

Lastly, the special issue is rounded off with three articles exploring the effects of the COVID-19 pandemic on specific countries. Lomelí offers an analysis of the health-care economy in Mexico, Bresser-Pereira examines the impact of the pandemic on the Brazilian economy, and López and Sturla present an essay on the taxation of large fortunes, focusing their analysis on Chile.

\section{Reflections arising from these essays}

The articles in this special edition address issues that go beyond the health emergency caused by COVID-19. While dealing with the effects of the pandemic, as outlined in the previous section, they also address global and regional structural aspects that predate the crisis. Thus, the health crisis is highlighting certain questions about the world economy that have arisen every time it has been faced with global shocks of a similar magnitude.

Over the last four decades, as the globalization of technology, finance and trade has intensified, the global economy has been repeatedly struck by economic crises that have exacerbated gaps between developed and developing countries, inequality within and between countries, political tensions and the real threats of environmental destruction.

These occurrences, accentuated particularly by the 2008 economic crisis, have highlighted the multiple failures of globalization in terms of its governance and the dysfunctional patterns of development that it has generated within countries. Rodrik (2011) has addressed these issues, analysing the tensions between globalization, democratic progress and national development policies. In this context, the role played by institutions is crucial in striking a proper balance between the three variables involved, something that is inherently complex, given the diversity and heterogeneity of the arrangements arrived at by different countries in accordance with their social peculiarities and preferences. Often these national arrangements diverge from the institutional forms of regulation, stability and legitimization that markets require. The deregulation of financial markets has led the global economy into sharper cycles of boom and bust and, ultimately, into new financial crises, which have worsened socioeconomic conditions within countries while fuelling anti-globalization social movements.

Where centre-periphery relations are concerned, the supremacy of deregulated financial markets over the real sectors of the world economy has had profound effects on the capability of countries, especially developing ones, to implement productive and trade policies that might enable them to close the internal and external gaps affecting them. The problems of global financial governance are paralleled in the way the multilateral trading system is organized, with restrictions that undermine the capabilities of the global South to implement national industrial policies of a developmentalist cast (Chang, 2002). 
In the face of these recurrent economic crises stemming from a globalization that has been dysfunctional in its governance and effects, a year after Rodrik published The Globalization Paradox, Paul Krugman released a manifesto whose central demand was to "end this depression now!". In this work, he argues that the recessionary bias present in global capitalism since 2008, which has now become not only an economic crisis but a humanitarian one in the fullest sense as a consequence of COVID-19, is rooted in the persistence of the austerity policies adopted by technocracies, which inhibit the fiscal and monetary stimuli necessary, in the opinion of Krugman and other Keynesian economists, to boost the drivers of aggregate demand that are required to reactivate global aggregate demand (Krugman, 2012). Various studies published over the past 10 years by the Economic Commission for Latin America and the Caribbean (ECLAC) have addressed the recessionary bias prior to the pandemic, one of whose fundamental determinants is the inadequacy of effective demand both globally and regionally. ECLAC (2016) is an example, with its idea of promoting Keynesian efficiency within the context of the multilateral system.

During these years in which the contradictions evinced by the current global economic system grew more acute, ECLAC refined its proposals for economic, social and environmental progress through a development strategy grounded in a rights-based approach. Time for Equality: Closing Gaps, Opening Trails (ECLAC, 2010) laid down the foundations for this strategy, in many instances anticipating criticisms of the world's current globalization model by globally prominent heterodox economists.

On the basis of the positions set out in that document, the contents of this strategy for development and the pursuit of equality were expanded and detailed in areas that have been a permanent part of the Commission's developmentalist messages: structural change for inclusive development (ECLAC, 2012) and the need for wide-ranging development compacts relating to taxation, production policy, the advancement of women, social cohesion and environmentally sustainable development, among other things (ECLAC, 2014). This strategy links strongly with the 2030 Agenda for Sustainable Development and the Sustainable Development Goals (ECLAC, 2016) and with the documents The Inefficiency of Inequality (ECLAC, 2018), which makes a solid case for the invalidity of the "big trade-off" between equality and efficiency posited by Okun (1975), and Building a New Future: Transformative Recovery with Equality and Sustainability (ECLAC, 2020), which presents the Commission's most recent proposal, one that, in the context of the pandemic, engages with the economic, social and environmental gaps that affect the region to produce a set of policy guidelines designed to create the conditions for a recovery accompanied by structural change and social inclusion.

Thus, while ECLAC has offered these perspectives, which address the key structural asymmetries holding back development in the region, including the technological and production gaps that limit its growth and the culture of privilege (an original take on the political economy puzzle explaining why it is impossible to reduce inequality in a broad sense and apply a progressive tax policy), other voices in the world have drawn attention to the harmful effects of the current pattern of globalization. They include the extensive output of Thomas Piketty and his interpretation of capitalism in the twenty-first century, drawing attention to data on the long-standing concentration of wealth in the developed economies and bringing the analysis of income distribution in the highest percentiles, particularly the top $1 \%$ (Piketty, 2014), into the debate and into the realm of economic research. Milanovic (2016) introduced the concept of global inequality, i.e. the average income differential between the world's inhabitants, into the discussion on distribution. According to Milanovic, inequality in global terms follows the Kuznets cycles of distributional dynamics within countries and income convergence between them. Although this is a contribution to research on the subject, Milanovic's theses have generated some controversy among analysts, some of whom argue that the way institutions are constructed and the pro-elite asymmetrical distribution of power within societies play a stronger role than the factors posited by Milanovic. The papers by Palma and by Bull and Robles included in this issue offer a view along these lines. 
In addition to the new debates on distribution presented in this special issue, the articles included here also open up a reflection on other crucial topics. One is the need for the State to recover its development policy role, given that markets alone, when left to their own devices in the spirit of the liberal philosophy of laissez-faire, have not succeeded in operating effectively to meet the requirements of vigorous growth with an appropriate distribution of its benefits among the different social actors, especially in the developing world. ECLAC (2020) addresses the role the State should play as an agent that generates compacts for the implementation of macroeconomic, industrial, social and environmental policies that can support sustainable structural change and social inclusion.

In line with these ideas, a number of economists have argued for the need to expand the role of the State in economic and development policies. Very notably, Mariana Mazzucato has advocated for the entrepreneurial role of the public sector in these policies. Specifically, she has pointed out that the State has been a key actor in investment and that its role in this has been obscured by the high-technology private sector, a segment that has been the subject of myth-making which overshadows the role of the public sector (Mazzucato, 2013). Setting out from this premise, she has linked the role of the State to the importance of technological innovation, revisiting a central aspect of classical political economy: the theory of value. Mazzucato's (2018) central question here is what wealth is and where value comes from. Moreover, she rightly asks what value really is and how much of what is presented as such is not rather appropriation or extraction of existing value. These questions are very important for the development prospects of the region, since the extractivist nature of its economies' productive matrices often concentrates value and does not necessarily create or increase wealth.

Consequently, the need to advance with the creation of new sectors or industries that generate genuine value gives the State a preponderant role in this objective, on the understanding that industrial policy and structural change are missions whose purpose is to meet strategic needs for societies (Mazzucato, 2021), such as food and health security, and other essential sectors. These approaches are certainly convergent with what ECLAC (2020) has proposed in relation to productive sectors with strong potential for the deployment of a new development strategy (renewable energies, sustainable mobility and urban spaces, health-care manufacturing and the bioeconomy, among others). The papers by Dosi and Savona included in this edition provide material for reflection on these topics.

Returning to the question of what will become of the world economy after the pandemic, there are various reflections on the subject, many of them just preceding the outbreak of the pandemic, which highlight the malaise being caused by the dynamics of global capitalism. Several of these have been alluded to in this section, and 2019 was a very prolific year for writing on the subject. First, mention may be made of Capital and Ideology by Thomas Piketty, who argues that the real essence of inequality is not purely economic or technological, but political and ideological. In an approach closer to Gramsci's than to Marx's, he argues that the driving force of history is not the class struggle, but hegemonic disputes over ideology. An important reflection of Piketty's is that it is possible to move on from capitalism to fairer societies in systems of participatory socialism or social federalism (Piketty, 2020).

On the other hand, the perspectives of Milanovic (2019) and Stiglitz (2019) are more oriented towards correcting the asymmetries of the current pattern of capitalism, i.e. moving beyond neoliberalism. Milanovic argues that capitalism, the one system prevailing in the world economy since the 1990s, has major flaws, such as inequality and corruption, but also advantages in terms of satisfying the autonomy of individuals, although he warns that it carries the moral cost of "material success" being exalted as their ultimate goal (individualism). Nonetheless, he is optimistic about the future of this system and argues that there are ways to reduce its excesses and inequities, something akin to what Stiglitz (2019) conceptualizes as a "progressive capitalism" that can emerge following the correction of aspects such as global corporate concentration, the failures of the financial industry, the 
capture of nation-States by business groups and the concentration of data arising from the activities of the new digital technology conglomerates. Action in these areas, Stiglitz believes, can help rebuild the foundations of a fairer and more inclusive capitalism.

A point of view that is more nuanced and perhaps more pessimistic than those of Piketty, Stiglitz and Milanovic is that expressed by Rodrik in 2020, at the height of the pandemic. He succeeds in interweaving his critique of the handling of the health crisis with the problems already affecting the world economy, systematized in his globalization-democracy-State triad, within the framework of neoliberal hegemony. Rodrik argues:

In short, COVID-19 may well not alter - much less reverse - tendencies evident before the crisis. Neoliberalism will continue its slow death. Populist autocrats will become even more authoritarian. Hyper-globalization will remain on the defensive as nation-states reclaim policy space. China and the US will continue on their collision course. And the battle within nation-states among oligarchs, authoritarian populists, and liberal internationalists will intensify, while the left struggles to devise a program that appeals to a majority of voters (Rodrik, 2020).

In these sentences, Rodrik evidently reaffirms the decline of the neoliberal phase of capitalism, but realistically points out that the recessionary biases which it generated over the past decade and which the pandemic exacerbated will continue to operate in the years to come and will persist strongly. Notwithstanding Rodrik's points, what is clear is the growing need to persevere with the idea of putting all intellectual, political and civic efforts at the service of a more balanced, fair and inclusive globalization, while putting those same efforts into a region, Latin America and the Caribbean, that is making progress in overcoming its structural obstacles to development and equality.

Seen in that light, the articles presented in this special edition of CEPAL Review bring readers a wealth of perspectives and reflections that we hope will enable them to broaden their understanding of the global and regional phenomena which will need addressing as a result of the new global shock brought by COVID-19.

\section{Bibliography}

Bielschowsky, R. (1998), "Evolución de las ideas de la CEPAL", Revista CEPAL, special issue (LC/G.2037-P), Santiago, Economic Commission for Latin America and the Caribbean (ECLAC), October.

Chang, H-J. (2002), Kicking away the ladder, development strategy in historical perspective, Anthem Press.

Chena, P. and E. Pérez Caldentey (2020), "Structural change and counter-reforms in Latin America: Necessity or possibility?", Cuadernos de Economía, vol. 39, No. 80, Universidad Nacional de Colombia.

ECLAC (Economic Commission for Latin America and the Caribbean) (2020), Building a New Future: Transformative Recovery with Equality and Sustainability (LC/SES.38/3-P/Rev.1), Santiago, October. (2018), The Inefficiency of Inequality (LC/SES.37/3-P), Santiago, May.

(2016), Horizons 2030: Equality at the Centre of Sustainable Development (LC/G.2660/Rev.1), Santiago. (2014), Covenants for Equality: Towards a Sustainable Future (LC/G.2586(SES.35/3)), Santiago.

(2012), Structural Change for Equality: An integrated approach to development (LC/G.2524(SES.34/3)), Santiago. (2010), Time for Equality: Closing Gaps, Opening Trails (LC/G.2432(SES.33/3)), Santiago.

Ffrench-Davis, R. and M. Torres (2021), "Neo-structuralism", The New Palgrave Dictionary of Economics, M. Vernengo, E.P. Caldentey and J. Barkley Rosser (eds.), Palgrave Macmillan.

Krugman, P. (2012), End this Depression Now!, W. W. Norton \& Company.

Mazzucato, M. (2021), Mission Economy: A Moonshot Guide to Changing Capitalism, Harper Business. (2018), The Value of Everything: Making and Taking in the Global Economy, Public Affairs.

_ (2013), The Entrepreneurial State: Debunking Public vs. Private Sector Myths, Anthem Press.

Milanovic, B. (2019), Capitalism, Alone: the Future of the System that Rules the World, Belknap Press. (2016), Global Inequality: A New Approach for the Age of Globalization, Belknap Press. 
Okun, A. (1975), Equality and Efficiency: The Big Tradeoff, Brooking Institutions Press.

Piketty, T. (2020), Capital and Ideology, Harvard University Press.

(2014), Capital in the Twenty-First Century, Belknap Press.

Prebisch, R. (1962), "El desarrollo económico de la América Latina y algunos de sus principales problemas", Boletín económico de América Latina, vol. 7, No. 1, February.

Rodrik, D. (2020), "Will COVID-19 Remake the World?" [online] https://www.project-syndicate.org/commentary/ will-covid19-remake-the-world-by-dani-rodrik-2020-04/spanish?barrier=accesspaylog.

_ (2011), The Globalization Paradox: Democracy and the Future of the World Economy, W. W. Norton \& Company.

Stiglitz, J. (2019), People, Power and Profits: Progressive Capitalism for an Age of Discontent, W. W. Norton \& Company.

Žižek, S. (2020), Pandemic!: COVID-19 Shakes the World, Polity. 